\title{
1 Banded iron formation to iron ore: a record of the evolution
}

\section{2 of Earth environments?}

3 K.A. Evans ${ }^{1}$, T.C. McCuaig ${ }^{2}$, D. Leach ${ }^{2}$, T. Angerer ${ }^{2}$, and S.G. Hagemann ${ }^{2}$

$4 \quad{ }^{1}$ Department of Applied Geology, Curtin University, GPO Box U1987, WA 6845,

$5 \quad$ Australia

$6{ }^{2}$ Core to Crust Fluid Systems Centre of Excellence, Centre for Exploration Targeting,

7 School of Earth and Environment, The University of Western Australia, Crawley, Perth,

8 WA 6009, Australia

9 ABSTRACT

10 Banded iron formations (BIF) are the protolith to most of the world's largest iron

11 ore deposits. Previous hypogene genetic models for Paleoproterozoic "Lake Superior"

12 BIF-hosted deposits invoke upwards, down-temperature flow of basinal brines via

13 complex silica and carbonate precipitation/dissolution processes. Such models are

14 challenged by the necessary $\mathrm{SiO}_{2}$ removal. Thermodynamic and mass balance constraints

15 are used to refine conceptual models of the formation of BIF-hosted iron-ore. These

16 constraints, plus existing isotope and halogen ratio evidence, are consistent with removal

17 of silica by down- or up-directed infiltration of high-pH hypersaline brines, with or

18 without a contribution from basinal brines. The proposed link to surface environments

19 suggest that Paleoproterozoic BIF-ore upgrade may provide a record of a critical time in

20 the evolution of the Earth's biosphere and hydrosphere.

\section{INTRODUCTION}


Banded iron formations (BIFs) record changing environmental conditions and are

24 a precursor to the world's largest iron ore deposits. Vast volumes of BIFs were deposited

25 on passive margins from ca. 2.6 Ga to the Great Oxygenation Event (GOE) at ca. 2.4 Ga

26 (e.g., Beukes and Gutzmer, 2008). After $1.85 \mathrm{Ga}$, formation of iron formations essentially

27 ceased until a restricted resurgence in the late Neoproterozoic (Young, 1976; Klein and

28 Beukes, 1993) and more recent minor occurrences.

29 The temporal distribution of BIFs records a complex interplay between a cooling

30 Earth and changes in mantle plume events, continental growth and tectonics, evolution of

31 the biosphere and an increased flux of iron to the hydrosphere, which in turn had a

32 fundamental control on the oxygen contents of the hydrosphere and redox state of the

33 oceans (Isley and Abbott, 1999; Holland, 2005; Bekker et al., 2010). In most giant

34 Paleoproterozoic BIF-hosted iron ore deposits ( $\sim 35 \mathrm{wt} \% \mathrm{Fe})$ the formation of high-grade

35 (>58 wt\% Fe) iron ore from Lake Superior-type BIF is thought to have occurred post 2.2

36 Ga, after the GOE (Taylor et al., 2001; Rasmussen et al., 2007; Thorne et al., 2009), so

37 the BIF-ore upgrade provides a record of the changing chemistry of the hydrosphere and

38 atmosphere in the Paleoproterozoic.

39 In the Hamersley province, Western Australia, the BIF-ore upgrade is proposed to

40 involve basinal brines, meteoric fluids, and supergene enrichment (e.g., Morris et al.,

41 1980; Barley et al., 1999; Taylor et al., 2001; Thorne et al., 2004, 2008). Silica removal is

42 proposed to occur by upward, down-temperature flow of basinal brines (e.g., Thorne et

43 al., 2004; Gutzmer et al., 2006; Thorne et al., 2008), and it is this stage of the BIF-ore

44 upgrade that is explored in this paper. 
The challenge for models that involve removal of $\mathrm{SiO}_{2}$ from $\mathrm{BIF}$ by down-

46 temperature flow is that quartz solubility decreases with decreasing temperature (e.g.,

47 Manning, 1994), so fluid that moves down-temperature is a poor agent for quartz

48 removal, unless large volumes of fluids enter the BIF in a silica-undersaturated state.

49 Here, we combine numerical constraints with petrological, geochemical and isotopic

50 characteristics of BIF-hosted iron ore from the Hamersley province, Western Australia, to

51 constrain the conditions associated with silica loss and carbonate precipitation, and

52 discuss the findings in the context of the temporal evolution of the world's atmosphere

53 and oceans.

\section{DEPOSIT SCALE PARAGENESIS}

55 The mineralogy of BIF, hydrothermaaltered BIF and iron ore varies (e.g., Thorne

56 et al., 2004; Rosiere et al., 2008; Mukhopadhyay et al., 2008; Angerer and Hagemann,

57 2010) but some features are sufficiently common to allow generalisation. BIF protolith

58 (Figs 1a;1b1;1b2) consists of magnetite- and chert-rich bands, iron silicates \pm diagenetic

59 carbonates. Initial hydrothermal alteration (Figs 1a;1b3;1b4), which may be gradational,

60 involves conversion of some of the silicates to carbonates. Subsequently, chert and quartz

61 are replaced by iron-bearing carbonate with, in some, cases conversion of magnetite to

62 hematite, often with no apparent change in volume. Reaction fronts may be gradual

63 (millimeter to decimeter scale) or knife-sharp on the scale of individual bands. Quartz

64 may be precipitated locally in fault zones within shear veins (e.g., Hagemann et al., 1999;

65 Thorne et al., 2010).

66 The carbonate-bearing alteration assemblage (Figs 1a;1b5;1b6) is separated from

67 almost pure (hypogene) hematite iron ore (Figs 1a;1b7;1b8) by a sharp or gradational 
68 reaction front. Carbonate loss is thought to occur without iron mobility on a scale greater

69 than a few $\mathrm{cm}$ (Taylor et al., 2001). Carbonate dissolution continues in the weathering

70 environment.

71 Upgrade of BIF in the Hamersley province, Western Australia, is thought to have

72 occurred from $2.15 \mathrm{Ga}$ onwards during the waning stages of the Opthalmian orogeny

73 (Rasmussen et al., 2007). There is evidence for extensional faulting and orogenic collapse

74 at the proposed time of ore upgrade (Müller et al., 2005) and it has been suggested that

75 topographic relief drove circulation of surface-derived waters through the fault system at

76 this time (e.g. Hagemann et al., 1999; Oliver and Dickens, 1999).

77 Constraints on ore upgrade in the Hamersley are provided by fluid inclusion,

78 isotopic, and halide concentration measurements. Fluid inclusions in carbonates are

79 hypersaline, up to $24 \mathrm{wt} \% \mathrm{CaCl}_{2}$ equivalent, which were trapped at temperatures between

80150 and $400{ }^{\circ} \mathrm{C}$ (Thorne et al., 2004; Brown et al., 2004), mainly at the lower end of this

81 range. Quartz-hosted fluid inclusions (e.g. Brown et al., 2004) records periods of quartz

82 growth, not quartz removal, so such inclusions may record either a different event, or a

83 later stage of the silica dissolution event that is of interest here.

84 Iron oxide oxygen isotopes in unaltered BIF have $\delta^{18} \mathrm{O}_{\text {VSMOw }}$ (Vienna Standard

85 Mean Ocean Water) between 4 and 13\%o, whereas hematite and magnetite in altered and

86 mineralized rocks have $\delta^{18} \mathrm{O}_{\text {vSmow }}$ between -9 to $-2.9 \%$ (Thorne et al., 2009). Carbon

87 isotopes of carbonate minerals lie between $-10 \%$ and $0 \%$, relative to Vienna Peedee

88 belemnite (VPDB). The lower values are typical of unaltered BIF. Values in altered rocks

89 could record equilbrium with either Paleoproterozoic ocean water or dolomite in the

90 underlying Wittenoom formation. Fluid inclusion $\mathrm{Na} / \mathrm{Br}$ and $\mathrm{Cl} / \mathrm{Br}$ ratios record 
91 overlapping populations of fluids: (1) seawater that has evaporated to halite saturation;

92 and (2) meteoric waters that interacted with evaporites (Thorne et al., 2010).

93 CONSTRAINTS ON SILICA REMOVAL AND CARBONATE PRECIPITATION

94 Fluids in Equilibrium with BIF

95 Quartz solubility is sensitive to pressure, temperature (e.g., Manning, 1994), pH

96 (Busey and Mesmer, 1977), and salinity (e.g., Shmulovich et al., 2006). Quartz and

97 carbonate solubilities were calculated as a function of pressure, temperature and salt

98 content (Fig. 2) using the methods outlined in the GSA Data Repository ${ }^{1}$. Calcite, rather

99 than iron carbonate was used for the models because data for iron carbonates is sparse,

100 but similar trends for iron carbonates are expected. Temperature is the first order control

101 on quartz solubility, whereas calcite solubility depends strongly on pressure (Fig. 2a).

102 Salinity-driven mineral precipitation/dissolution is minor for geothermal gradients <50

$103{ }^{\circ} \mathrm{C} \mathrm{km}^{-1}$ (Fig. 2b). There is no geothermal gradient for which silica dissolution is

104 accompanied by carbonate precipitation in the observed quantities, so it is necessary to

105 consider infiltration of out-of-equilibrium fluids.

106

107 Fluid out of Equilibrium with BIF

108 Infiltration of high-pH, out-of-equilibrium fluid can drive quartz removal via up-

109 or down-temperature flow, because quartz is 4 orders of magnitude more soluble at pH 9

110 than it is at pH 6 (Busey and Mesmer, 1977). The desilicification/carbonation and

111 oxidation fronts observed in BIFs are sufficiently sharp that they can be treated as

112 advective chromatographic fronts; broadening by diffusion, dispersion and kinetic 
113 broadening can be neglected. The ratio of the distance traveled by a fluid to that of

114 associated reaction front is given by

115

$$
\frac{d_{\text {fluid }}}{d_{\text {rock }}}=\frac{c_{\text {i,rock,final }}-c_{\text {i,rock,initial }}}{\theta\left(c_{\text {i,fluid,initial }}-c_{\text {i,fluid,final })}\right.},
$$

116 (adapted from Evans et al., 2003). $d$ is the position of the front relative to the infiltration

117 horizon in meters, $c_{\mathrm{i}}$ is the concentration of the reactant of interest in moles $\mathrm{m}^{-3}$, and $\theta$ is 118 porosity.

119 Relative positions of carbonation, desilicification, and oxidation fronts were 120 calculated using the values given in Table DR1 (in the Data Repository), which are based 121 on the assumption of infiltration an out-of-equilibrium, $\mathrm{pH}$ 9, $\mathrm{SiO}_{2}$-free, $\mathrm{CO}_{2}$-rich, $\mathrm{O}_{2}$ 122 bearing fluid $\left(\mathrm{O}_{2}\right.$ at $10 \%$ of present-day values $)$. Front positions were normalized to that 123 of the most advanced carbonation front (Fig. 1b). The oxidation front is predicted to 124 proceed the smallest distance, as observed, though the position of this front is modified

125 by post-hypogene meteoric fluid and supergene processes. The carbonation front is

126 predicted to advance further than the desilicification front for any reasonable combination

127 of input parameters. In reality, the desilicification front coincides with a sharp increase in

128 carbonate content, which suggests a reaction-induced porosity control on fluid

129 infiltration.

\section{Volumes of Fluid Flow}

131 The relationship between time-integrated fluid flux and silica removal for

132 hydrothermal alteration where pressure, temperature and fluid composition gradients are

133 fixed, and for constant fluid flow rates is given by

$$
Q=\frac{\Delta n_{\mathrm{SiO}_{2}}}{\left(d c_{\mathrm{SiO}_{2} / d l}\right)},
$$


135 (c.f. Evans and Bickle, 1999, their equation 6). $Q$ is the time-integrated fluid flux, in

136 cubic meters of fluid per square meter of rock, $\Delta n_{\mathrm{SiO}_{2}}$ is the $\mathrm{SiO}_{2}$ removed from the

137 volume $\left(\right.$ moles $\left.\mathrm{m}^{-3}\right), \mathrm{c}_{\mathrm{SiO}_{2}}$ is the concentration of $\mathrm{SiO}_{2}$ in the fluid in $\left(\right.$ moles $\left.\mathrm{m}^{-3}\right)$, and $l$ is

138 distance along the flow path (m). This expression is based on mass balance and can be

139 applied to in- or out-of-equilibrium situations. Calculations were made for flow up- or

140 down-temperature of a $\mathrm{pH}$ 9, silica-undersaturated fluid, such as might be derived from

141 an ultramafic lithology or hypersaline evaporite-derived fluid. $\mathrm{pH}$ is assumed to drop

142 from 9 to 5 during equilibration. $d c_{\mathrm{SiO}_{2}} / d \mathrm{pH}$ was calculated from Busey and Mesmer

143 (1977) and checked against HCh output (Shvarov and Bastrakov, 1999).

144 Flow volumes were calculated for a single cubic meter of rock undergoing $\mathrm{pH}$ -

145 driven quartz dissolution and scaled to estimate the volume needed to produce the

146 observed $\mathrm{SiO}_{2}$ depletion on a scale comparable to observed small iron ore deposits $(3 \times$

$14710^{8} \mathrm{~m}^{3}$ ). The volume of fluid required is approximately $\sim 10^{9} \mathrm{~m}^{3}$.

\section{DISCUSSION AND CONCLUSIONS}

149 The observed silica removal and carbonate precipitation needed for formation of a

150 kilometer-scale BIF-hosted Fe deposit is inconsistent with in-equilibrium fluid flow (Fig.

151 2), but could be produced by pervasive infiltration of $\sim 10^{9} \mathrm{~m}^{3}$ of a high $\mathrm{pH}(\mathrm{pH}>9)$ fluid

152 flowing up- or down- temperature.

153 Density- or topography-driven infiltration (McLellan et al., 2004) of dense

154 hypersaline brines evolved on continental margins (Fig. 3) provides a plausible source of

155 high-pH fluid. The $\mathrm{pH}$ of hypersaline lakes today is up to 10 , and the $\mathrm{CO}_{2}$ content is

156 high; reported alkalinities exceed 10,000 $\mathrm{mg} \mathrm{liter}^{-1}$ (Gosselin et al., 1994). These brines

157 form on marginal platforms (Leach et al., 2010) and were present on the north Yilgarn 
158 margin in the Palaeoproterozoic (El Tabakh et al., 1999) and in Mesoproterozoic

159 dolomitic argillites in the western United States (Gonzalez-Alvarez and Kerrich, 2011).

160 The Yilgarn and Pilbara cratons may not have been adjacent at the time of ore formation,

161 and the latitude of the Pilbara margin at that time is poorly known but existing constraints

162 place the latitude within the range of those required for evaporite formation ( $\mathrm{Li}, 2000)$.

163 Fault zones in similar environments today are sufficiently permeable that proposed

164 volumes could have flowed on a geologically reasonable timescale (Jones et al., 2002).

165 Carbon and oxygen isotopes of early carbonate and iron oxides in mineralised BIF

166 are consistent with seawater derivation from Palaeoproterozoic seawater. High salinities

167 and $\mathrm{Na} / \mathrm{Br}$ and $\mathrm{Cl} / \mathrm{Br}$ ratios record fluids typical of seawater that has evaporated to halite

168 saturation (Thorne et al., 2010), which is also consistent with an involvement of

169 evaporite-derived fluids. Temperatures of up to $250{ }^{\circ} \mathrm{C}$ are consistent with fluid inclusion

170 evidence, and with other environments where voluminous quantities of surface-derived

171 fluids infiltrate basement rocks (e.g. Gleeson and Yardley., 2003). However,

172 temperatures $>300{ }^{\circ} \mathrm{C}$ recorded by early assemblages at Mt. Tom Price require a separate

173 high-temperature alteration stage. $\mathrm{SiO}_{2}$ deposition in outflow zones from the flow system

174 described have not been recorded, to date, but may prove difficult to recognize given that

175 chert was a common sedimentary rock at this time.

176 Some geometric constraints in mineralized Pilbara BIFs favour an upwards

177 flowing fluid (e.g. Dalstra and Rosiere, 2004). The Wittenoom formation underlies many

178 of the ore-bearing units, and has been proposed as a way for basinal brines to access the

179 BIF (e.g. Taylor et al., 2001). Dolomite in the Wittenoom formation contains numerous

180 shale bands (Davy, 1975), and is separated from the BIF by the Si-bearing Mt McRae 
181 shale and Sylvia Formation, so fluids from this unit would be at, or close to, $\mathrm{SiO}_{2}$

182 saturation, unless fluids were focused solely within shale-free regions of the dolomite,

183 such as the Paraburdoo Member (Thorne and Tyler, 1997). If this were the case then the

184 dolomite in the Wittenoom formation could have acted as an aquifer that supplied

185 overlying iron formations with fluids derived either from faults that focused either down-

186 flowing evaporitic brines with or without a contribution from upwards-flowing basinal

187 brines, as suggested by previous workers (e.g. Taylor et al., 2001).

188 Mafic and ultramafic rocks are present in the Pilbara (e.g., Barnes and Hoatson,

189 1994) and can equilibrate with water to provide high $\mathrm{pH}$ fluids, but such fluids are

190 unlikely to have reached the BIF without interacting with Si-bearing rocks such as the Mt

191 McRae shale.

192 Oxidized, sulfur-bearing, hypersaline brines produced on basin margins since 2.0

193 Ga have been linked to base metal sulfide deposition, including MVT (Mississippi Valley

194 type) and SEDEX-Pb-Zn deposits (Leach et al., 2010). Such deposits older than $2.02 \mathrm{Ga}$

195 have not been found; Archaean and Paleoproterozoic oceans were reduced and largely

196 sulfur-depleted (e.g., Farquhar et al., 2010), so marginal hypersaline brines at 2.2 Ga, at

197 the time of ore upgrade, could have had a significantly different composition to those

198 today. It is interesting to speculate whether redox controls related to mobilization,

199 transport, and deposition of $\mathrm{Pb}$ and $\mathrm{Zn}$ by Palaeoproterozoic evaporite-derived brines,

200 such as a lack of sulfur (Leach et al., 2010) lack of oxidized source rocks and aquifers, or

201 reduction of sulfate via rock-buffering in the immediate sub-surface, may have prevented

202 formation of these deposit types prior to $2.02 \mathrm{Ga}$.

203 


\section{ACKNOWLEDGMENTS}

Rob Kerrich, Hilke Dalstra, and an anonymous reviewer are thanked for perceptive, knowledgeable reviews. Thanks for funding and support are due to a

207 Curtin Research and Teaching Fellowship, Australian Research Council Discovery

S. Hagemann. This is TiGeR publication number 423.

\section{REFERENCES CITED}

211 Angerer, T., and Hagemann, S.G., 2010, The BIF-hosted high-grade iron ore deposits in the Archean Koolyanobbing Greenstone Belt, Western Australia: Structural control on synorogenic- and weathering-related magnetite-, hematite-, and goethite-rich iron ore: Economic Geology and the Bulletin of the Society of Economic Geologists, v. 105, p. 917-945, doi:10.2113/gsecongeo.105.5.917.

Barley, M.E., Pickard, A.L., Hagemann, S.G., and Folkert, S.L., 1999, Hydrothermal origin of the 2 billion year old Mount Tom Pirce giant irohn ore deposit, Hamersley province, Western Australia: Mineralium Deposita, v. 34, p. 784-789.

Bekker, A., Slack, J.F., Planavsky, N., Krapez, B., Hofmann, A., Konhauser, K.O., and Rouxel, O.J., 2010, Iron formation: The sedimentary product of a complex interplay among mantle, tectonic, oceanic, and biospheric processes: Economic Geology and the Bulletin of the Society of Economic Geologists, v. 105, p. 467-508, doi:10.2113/gsecongeo.105.3.467.

Bekker, A., and Holland, H.D., 2012, Oxygen overshoot and recovery during the early Paleoproterozoic: Earth and Planetary Science Letters, v. 317, p. 295-304, doi:10.1016/j.epsl.2011.12.012. 
227 Beukes, N.J., and Gutzmer, J., 2008, Origin and Paleoenvironmental Significance of

228 Major Iron Formations at the Archean-Paleoproterozoic Boundary, in Hagemann,

229 S.R.C.G.J.B.N.J., ed., Banded Iron Formation-Related High-Grade Iron Ore, Volume

230 15: Reviews in Economic Geology, p. 5-47.

231 Barnes, S.J., and Hoatson, D.M., 1994, The Munni-Munni Complex, Western-

232 Australia - Stratigraphy, structure and petrogenesis: Journal of Petrology, v. 35,

233 p. 715-751, doi:10.1093/petrology/35.3.715.

234 Brown, M.C., Oliver, N.H.S., and Dickens, G.R., 2004, Veins and hydrothermal fluid

235 flow in the Mt. Whaleback Iron Ore District, eastern Hamersley Province, Western

236 Australia: Precambrian Research, v. 128, p. 441-474,

237 doi:10.1016/j.precamres.2003.09.013.

238 Busey, R.H., and Mesmer, R.E., 1977, Ionization equilibria of silicic-acid and

239 polysilicate formation in aqueous sodium-chloride Solutions to 300-Degrees-C:

240 Inorganic Chemistry, v. 16, p. 2444-2450, doi:10.1021/ic50176a004.

241 Dalstra, H.J., and Rosiere, C.A., 2004, Structural controls on high-grade iron ores hosted

242 by banded iron formation: a global perspective, in Hagemann, S., Rosiere, C.A.,

243 Gutzmer, J., and Beukes, N.J., eds., Banded iron formation-related high-grade iron

244 ore, Volume 15: Littleton, Colorado, Society of Economic Geologists, p. 73-106.

245 Davy, R., 1975, A geochemical study of a dolomite-BIF transition in the lower part of the

246 Hamersley Group: Annual Report of the Geological Survey of Western Australia,

247 v. 1974, p. $88-101$.

248 El Tabakh, M., Grey, K., Pirajno, F., and Schreiber, B.C., 1999, Pseudomorphs after

249 evaporitic minerals interbedded with 2.2 Ga stromatolites of the Yerrida basin, 
Western Australia: Origin and significance: Geology, v. 27, p. 871-874, doi:10.1130/0091-7613(1999)027<0871:PAEMIW>2.3.CO;2.

252 Evans, K.A., and Bickle, M.J., 1999, Determination of time-integrated metamorphic fluid

253 fluxes from the reaction progress of multivariant assemblages: Contributions to

254 Mineralogy and Petrology, v. 134, p. 277-293, doi:10.1007/s004100050484.

255 Evans, K.A., Gandy, C.J., and Banwart, S.A., 2003, Mineralogical, numerical and 256 analytical studies of the coupled oxidation of pyrite and coal: Mineralogical

257 Magazine, v. 67, p. 381-398, doi:10.1180/0026461036720107.

258 Farquhar, J., Wu, N.P., Canfield, D.E., and Oduro, H., 2010, Connections between sulfur

259 cycle evolution, sulfur isotopes, sediments, and base metal sulfide deposits:

260 Economic Geology and the Bulletin of the Society of Economic Geologists, v. 105,

261 p. 509-533, doi:10.2113/gsecongeo.105.3.509.

262 Gleeson, S.A., and Yardley, B.W.D., 2003, Surface-derived fluids in basement rocks;

263 inferences from palaeo-hydrothermal systems: Journal of Geochemical Exploration,

264 v. $78-79$, p. $61-65$.

265 Gonzalez-Alvarez, I., and Kerrich, R., 2011, Trace element mobility in dolomitic

266 argillites of the Mesoproterozoic Belt-Purcell Supergroup, Western North America:

267 Geochimica et Cosmochimica Acta, v. 75, p. 1733-1756,

268 doi:10.1016/j.gca.2011.01.006.

269 Gosselin, D.C., Sibray, S., and Ayers, J., 1994, Geochemistry of K-rich alkaline Lakes,

270 Western Sandhills, Nebraska, USA: Geochimica et Cosmochimica Acta, v. 58,

271 p. 1403-1418, doi:10.1016/0016-7037(94)90545-2. 
272 Gutzmer, J., Mukhopadhyay, J., Beukes, N.J., Pack, A., Hayashi, K., and Sharp, Z.D.,

2732006 , Oxygen isotope composition of hematite and genesis of high grade BIF-hosted

274 iron ores, in Kesler, S.E., and Ohmoto, H., eds., Evolution of Early Earth's

275 Atmosphere, Hydrosphere, and Biosphere-Constraints from Ore Deposits:

276 Geological Society of America Memoir 198, p. 257-268.

277 Hagemann, S.G., Barley, M.E., and Folkert, S.L., 1999A hydrothermal origin for the 278 giant BIF-hosted Tom Price iron ore deposit, in Stanley, C.J., ed., Mineral Deposits,

279 Processes to Processing: Rotterdam, Balkema, p. 41-44.

280 Holland, H.D., 2005, Sedimentary mineral deposits and the evolution of Earth's near-

281 surface environments: Economic Geology and the Bulletin of the Society of

282 Economic Geologists, v. 100, p. 1489-1509.

283 Isley, A.E., and Abbott, D.H., 1999, Plume-related mafic volcanism and the deposition of 284 banded iron formation: Journal of Geophysical Research. Solid Earth, v. 104,

285 p. 15461-15477, doi:10.1029/1999JB900066.

286 Jones, G.D., Whitaker, F.F., Smart, P.L., and Sanford, W.E., 2002, Fate of reflux brines

287 in carbonate platforms: Geology, v. 30, p. 371-374, doi:10.1130/00917613(2002)030<0371:FORBIC>2.0.CO;2.

289 Klein, C., and Beukes, N.J., 1993, Sedimentology and geochemistry of the glaciogenic

290 Late Proterozoic Rapitan Iron Formation in Canada: Economic Geology, v. 88, 291 p. $542-565$, doi:10.2113/gsecongeo. 88.3.542.

292 Leach, D.L., Bradley, D.C., Huston, D., Pisarevsky, S.A., Taylor, R.D., and Gardoll, S.J., 293 2010, Sediment-hosted lead-zinc deposits in Earth history: Economic Geology and 
the Bulletin of the Society of Economic Geologists, v. 105, p. 593-625,

295 doi:10.2113/gsecongeo.105.3.593.

296 Li, Z.X., 2000, Palaeomagnetic evidence for unification of the North and West Australian

297 cratons by ca.1.7 Ga: New results from the Kimberley Basin of northwestern

298 Australia: Geophysical Journal International, v. 142, p. 173-180, doi:10.1046/j.1365-

$299 \quad 246 x .2000 .00143 . x$

300 Manning, C.E., 1994, The solubility of quartz in $\mathrm{H}_{2} \mathrm{O}$ in the lower crust and upper

mantle: Geochimica et Cosmochimica Acta, v. 58, p. 4831-4839, doi:10.1016/0016-

303 Morris, R.C., Thornber, M.R., and Ewers, W.E., 1980, Deep-seaterd iron ores from

304 banded iron formation.: Nature, v. 288, p. 250-252.

305 McLellan, J.G., Oliver, N.H.S., and Schaubs, P.M., 2004, Fluid flow in extensional

306 environments; numerical modelling with an application to Hamersley iron ores:

307 Journal of Structural Geology, v. 26, p. 1157-1171, doi:10.1016/j.jsg.2003.11.015.

308 Mukhopadhyay, J., Gutzmer, J., Beukes, N.J., and Bhattacharya, H.N., 2008, Geology

309 and genesis of the major banded iron formation-hosted high-grade iron ore deposits

310 of India, in Hagemann, S.R., ed., Banded Iron Formation-Related High-Grade Iron

311 Ore: Reviews in Economic Geology, v. 15, p. 291-316.

312 Oliver, N.H.S. and Dickens, G.R., 1999, Hematite ores of Australia formed by

313 syntectonic heated meteoric fluids, Mineral Deposits: Processes to Processing, v. 1-

314 2, p. 889-892.

315 Rasmussen, B., Fletcher, I.R., Muhling, J.R., Thorne, W.S., and Broadbent, G.C., 2007,

316 Prolonged history of episodic fluid flow in giant hematite ore bodies: Evidence from 

in situ U-Pb geochronology of hydrothermal xenotime: Earth and Planetary Science

318 Letters, v. 258, p. 249-259, doi:10.1016/j.eps1.2007.03.033.

319 Rosiere, C.A., Spier, C.A., Rios, F.J., and Suckau, V.E., 2008, The Itabirites of the

320 Quadrilatero Ferrifero and related high-grade ion ore deposits: An overview, in

321 Hagemann, S.R., ed., Banded Iron Formation-Related High-Grade Iron Ore: Reviews 322 in Economic Geology, v. 15, p. 223-254.

323 Shmulovich, K.I., Yardley, B.W., and Graham, C.M., 2006, The solubility of quartz in 324 crustal fluids: experiments and general equations for salt solutions and $\mathrm{H}_{2} \mathrm{O}-\mathrm{CO}_{2}$

325 mixtures at $400^{\circ}-800^{\circ} \mathrm{C}$ and $0.1-0.9$ GPa: Geofluids, v. 6, p. 154-167, 326 doi:10.1111/j.1468-8123.2006.00140.x.

327 Shvarov, Y., and Bastrakov, E., 1999, HCh: a software package for geochemical 328 equilibrium modelling. User's Guide: Canberra, Australian Geological Survey $329 \quad$ Organisation.

330 Taylor, D., Dalstra, H.J., Harding, A.E., Broadbent, G.C., and Barley, M.E., 2001, 331 Genesis of high-grade hematite orebodies of the Hamersley province, Western 332 Australia: Economic Geology and the Bulletin of the Society of Economic 333 Geologists, v. 96, p. 837-873.

334 Thorne, W.S., Hagemann, S.G., and Barley, M., 2004, Petrographic and geochemical 335 evidence for hydrothermal evolution of the North Deposit, Mt Tom Price, Western 336 Australia: Mineralium Deposita, v. 39, p. 766-783, doi:10.1007/s00126-004-0444-x. 337 Thorne, W., Hagemann, S., Webb, A., and Clout, J., 2008, Banded iron formation-related 338 iron ore deposits of the Hamersley Province, Western Australia, in Hagemann, S.R., 
$340 \quad$ Geology, v. 15, p. 197-221.

341 Thorne, W., Hagemann, S., Vennemann, T., and Oliver, N., 2009, Oxygen isotope

342 compositions of iron oxides from high-grade BIF-hosted iron ore deposits of the

343 Central Hamersley Province Western Australia: Constraints on the evolution of

344 hydrothermal fluids: Economic Geology and the Bulletin of the Society of Economic

345 Geologists, v. 104, p. 1019-1035, doi:10.2113/gsecongeo.104.7.1019.

346 Thorne, W., Hagemann, S., and Banks, D., 2010, Halogen and cation constraints on the

347 origin of hydrothermal fluids forming high-grade iron ore deposits in the Hamersley

348 Province, Western Australia: Smart Science for Exploration and Mining, v. 1-2,

349 p. 582-584.

350 Thorne, A.M., and Tyler, I.M., 1997, Mount Bruce, Western Australia., 1:250 000

351 geological series explanatory notes., Volume Sheet SF 50-11.

352 Young, G.M., 1976, Iron-formation and glaciogenic rocks of the Rapitan Group,

353 Northwest Territories, Canada: Precambrian Research, v. 3, p. 137-158,

354 doi:10.1016/0301-9268(76)90030-9.

\section{FIGURE CAPTIONS}

356 Figure 1. (a) Commonly observed banded iron formation (BIF) alteration stages related to

357 the formation of iron ore and their characteristics. (b1-8) Polished blocks and

358 photomicrographs of the typical alteration stages $(\mathrm{mplH}-$ microplaty hematite, mar-

359 martite). (c) Results of mass balance calculations to determine the relative distances

360 moved by decarbonation, desilicification and oxidation fronts. Values indicate distance

361 traveled by front relative to the carbonation front for a solution with 1 mol liter ${ }^{-1} \mathrm{CO}_{2}$. 
363 Figure 2. Results of thermodynamic calculations of $\mathrm{SiO}_{2}$ and calcite solubility as a

364 function of pressure and temperature (a), and temperature and salt concentration (b).

365

366 Figure 3. Proposed genetic model for desilicification of banded iron formation (BIF) by a

367 density-driven, hypersaline, high-pH brine.

368

$369{ }^{1}$ GSA Data Repository item 2012xxx, xxxxxxxx, is available online at

370 www.geosociety.org/pubs/ft2012.htm, or on request from editing@geosociety.org or

371 Documents Secretary, GSA, P.O. Box 9140, Boulder, CO 80301, USA. 